\title{
Micro-solid oxide fuel cells Status, challenges, and chances
}

\section{Journal Article}

\section{Author(s):}

Evans, Anna; Bieberle-Hütter, Anja; Galinski, Henning; Rupp, Jennifer L.M.; Ryll, Thomas; Scherrer, Barbara; Tölke, René; Gauckler, Ludwig J.

\section{Publication date:}

2009

\section{Permanent link:}

https://doi.org/10.3929/ethz-b-000019047

\section{Rights / license:}

In Copyright - Non-Commercial Use Permitted

\section{Originally published in:}

Monatshefte für Chemie 140(9), https://doi.org/10.1007/s00706-009-0107-9 


\title{
Micro-solid oxide fuel cells: status, challenges, and chances
}

\author{
Anna Evans · Anja Bieberle-Hütter · Henning Galinski • \\ Jennifer L. M. Rupp · Thomas Ryll · Barbara Scherrer • \\ René Tölke $\cdot$ Ludwig J. Gauckler
}

Received: 10 November 2008/Accepted: 18 November 2008/Published online: 19 February 2009

(C) Springer-Verlag 2009

\begin{abstract}
Micro-solid oxide fuel cells (micro-SOFC) are predicted to be of high energy density and are potential power sources for portable electronic devices. A microSOFC system consists of a fuel cell comprising a positive electrode-electrolyte-negative electrode (i.e. PEN) element, a gas-processing unit, and a thermal system where processing is based on micro-electro-mechanical-systems fabrication techniques. A possible system approach is presented. The critical properties of the thin film materials
\end{abstract}

A. Evans $(\bowtie) \cdot$ B. Scherrer

Nonmetallic Inorganic Materials, ETH Zurich,

Wolfgang-Pauli-Strasse 10, HCI G536,

8093 Zurich, Switzerland

e-mail: anna.evans@mat.ethz.ch

A. Bieberle-Hütter

Nonmetallic Inorganic Materials, ETH Zurich, Wolfgang-Pauli-Strasse 10, HCI G539,

8093 Zurich, Switzerland

H. Galinski

Nonmetallic Inorganic Materials, ETH Zurich, Wolfgang-Pauli-Strasse 10, HCI G528,

8093 Zurich, Switzerland

\section{J. L. M. Rupp}

Nonmetallic Inorganic Materials, ETH Zurich, Wolfgang-Pauli-Strasse 10, HCI G533,

8093 Zurich, Switzerland

T. Ryll · R. Tölke

Nonmetallic Inorganic Materials, ETH Zurich, Wolfgang-Pauli-Strasse 10, HCI G530,

8093 Zurich, Switzerland

\section{J. Gauckler}

Nonmetallic Inorganic Materials, ETH Zurich,

Wolfgang-Pauli-Strasse 10, HCI G535,

8093 Zurich, Switzerland used in the PEN membrane are discussed, and the unsolved subtasks related to micro-SOFC membrane development are pointed out. Such a micro-SOFC system approach seems feasible and offers a promising alternative to stateof-the-art batteries in portable electronics.

Keywords Micro-solid oxide fuel cell · Thin film deposition - MEMS - Microfabrication · Gas processing $\cdot$ Thermal system

\section{Introduction}

The demand for small mobile energy storage devices and mobile power delivery systems has increased over the past few years with the development of portable electronics. Fuel cells, electrochemical devices that convert chemical energy directly into electricity, are often discussed to satisfy this demand. Several different types of fuel cells, classified according to the material of the electrolyte, have been developed and reported in the literature.

The comparison of the energy densities of different energy carriers shows that propane is the most favorable among the liquid fuels (see Table 1). When combining the fuels in their containers with the fuel cells into one system for mobile energy delivery, then solid oxide fuel cells (SOFC) with a ceramic electrolyte operating on propane have the highest energy density normalized to volume or weight of all fuel cells compared to proton exchange membrane fuel cells (PEMFC) and direct methanol fuel cells (DMFC) [1]. In Fig. 1 the anticipated energy densities of different micro-fuel cell systems are compared with those of advanced batteries. From this comparison, it is obvious that a laptop will operate four to five times longer with a micro-SOFC compared to lithium-ion batteries. It 
Table 1 Energy densities of different liquid fuels

\begin{tabular}{lll}
\hline Fuel type & $\begin{array}{c}\text { Energy density } \\
\text { by mass/MJ/kg }\end{array}$ & $\begin{array}{l}\text { Energy density } \\
\text { by volume/MJ/dm }\end{array}$ \\
\hline $\begin{array}{l}\text { LPG (liquid pressurized } \\
\text { gas, } 8 \text { bar) propane }\end{array}$ & 49.6 & 25.3 \\
$\quad$ Ethanol & 30.0 & 24.0 \\
Methanol & 19.7 & 15.6 \\
Hydrogen liquid in & 6.1 & 10.1 \\
$\quad$ vessel, pressurized & & \\
$\quad\left(300\right.$ bar, $\left.25^{\circ} \mathrm{C}\right)$ [73] & & 3.2 \\
Hydrogen in metal hydride & 1.2 & \\
$\quad\left(25^{\circ} \mathrm{C}\right)$ [73] & & \\
\hline
\end{tabular}

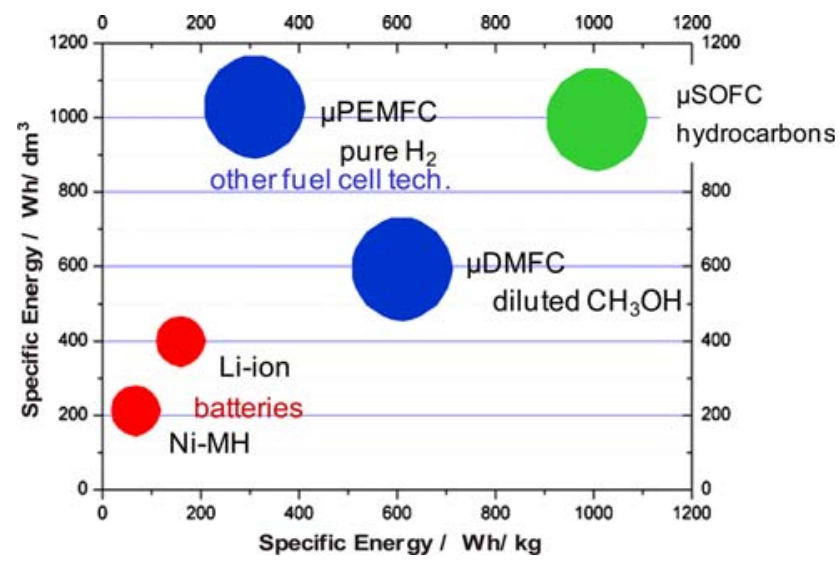

Fig. 1 Energy densities of batteries and anticipated energy densities of micro-fuel cells including their fuel tank (adapted from [71])

also becomes clear that micro-PEMFCs only have real advantages over batteries when volume is an important issue and that micro-DMFCs lead to a two to three times longer operation than batteries. These advantages are basically due to the high energy densities of the fuels used in micro-fuel cells.

The working principle of all fuel cell types is very similar and is shown for a SOFC in Fig. 2. The driving force for oxygen diffusion through the electrolyte is the difference in oxygen partial pressure between the anode (low $\mathrm{pO}_{2}$ ) and the cathode (high $\mathrm{pO}_{2}$ ). The open-circuit voltage (OCV) corresponds to the potential across the SOFC without any applied current and is given by the Nernst equation:

$E=\frac{R T}{4 F} \ln \left(\frac{p^{\mathrm{O}_{2}, \text { high }}}{p^{\mathrm{O}_{2}, \text { low }}}\right)$

where $R$ is the universal gas constant $\left(R=8.314 \mathrm{JK}^{-1}\right.$ $\mathrm{mol}^{-1}$ ), $T$ the temperature, and $F$ the Faraday constant $\left(F=96485.3 \mathrm{C} \mathrm{mol}^{-1}\right)$.

State-of-the-art lithium-ion and nickel-metal-hydride batteries suffer from relatively low energy densities and hence from a short battery-availability time between charging cycles and long charging times. SOFCs, by contrast, have an energy density that is higher by a factor of 2 4 and can be charged immediately by changing the fuel container [2]. If use is made of a common fuel, such as butane, it is possible to revert to well-accepted and approved technologies for the fuel gas container, such as those used in firelighters and camping gas equipment. These fuel containers are available worldwide; hence, the user can reload the fuel cell anywhere and is geographically independent when using the electronic device.

Solid oxide fuel cells are conventionally used in large stationary power plants (kilowatt to megawatt range) and are not usually intended for portable devices. This is

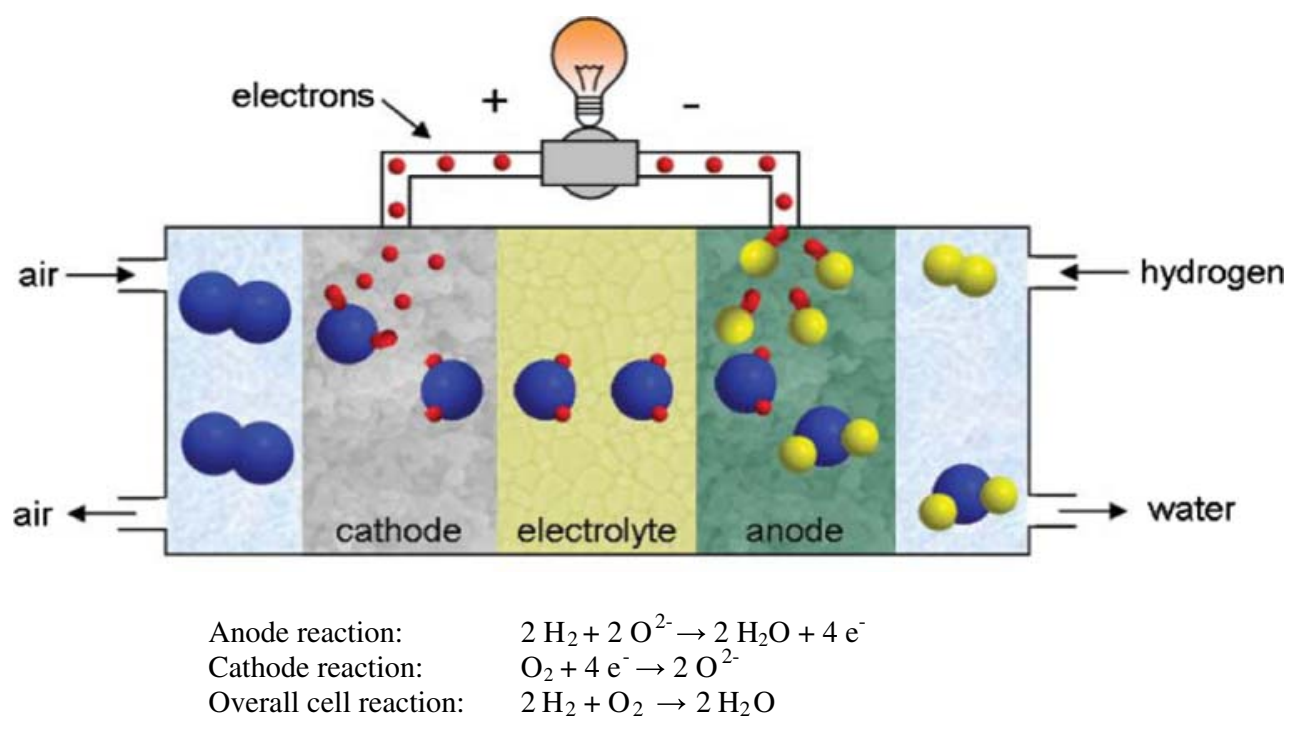

Fig. 2 Operating principle of a solid oxide fuel cell converting chemical energy into electricity at high temperatures (adapted from [70]) 
because of their high operating temperature, made necessary by the ionic electrolyte, which requires high temperatures for good ionic conductivity. Hence, conventional SOFCs operate at around $900{ }^{\circ} \mathrm{C}$. For small portable devices, this temperature is too high to keep the outside of the device at a maximum of about $35{ }^{\circ} \mathrm{C}$. This means that the operating temperature of SOFCs has to be drastically reduced if they are to be used for portable applications. This can be achieved by reducing the thickness of the electrolyte, whereby the shorter diffusion path results in a smaller ohmic resistance. In addition, the operating temperature can be reduced by optimizing the materials. A ceria-based electrolyte, for example, has better ionic conducting properties at low temperatures than a zirconiabased electrolyte. The combination of micro-electromechanical-systems (MEMS) fabrication techniques and thin film deposition technology can be used to develop miniaturized SOFCs. These micro-SOFC systems have an operation principle that is identical to the SOFCs used for stationary applications and constitute potential power sources for low power applications in the $1-20-\mathrm{W}$ range as battery replacements in small electronic devices.

This paper introduces the system approach for microSOFC, describes and discusses critical materials properties in such a system, in particular the properties of thin films used in free-standing membranes, and discusses the unsolved subtasks related to micro-SOFC membrane development.

\section{Micro-SOFC system}

A micro-SOFC system comprises an electrochemical active fuel cell membrane, a gas-processing unit, and a thermal system. The fuel tank and the control unit are considered as external elements. Such micro-SOFC systems have been proposed by Lilliputian Systems (Wilmington, MA) [3, 4] and ONEBAT (Zurich, Switzerland) [5-22]. The ONEBAT project focuses on the development of an SOFC system as a battery replacement for small portable electronic equipment, such as laptops and portable digital assistants, as well as small medical and industrial devices. The overall aim is to develop a microSOFC where "micro" signifies, on the one hand, the small overall size of an SOFC being much smaller than conventional SOFCs and, on the other hand, microfabrication technologies that are traditionally not used for the fabrication of SOFCs.

The ONEBAT micro-SOFC system consists of the positive-electrode-electrolyte-negative electrode (PEN) fuel cell element, a gas-processing unit, and a thermal system. The system layout is shown schematically in Fig. 3. The different components of the ONEBAT micro-

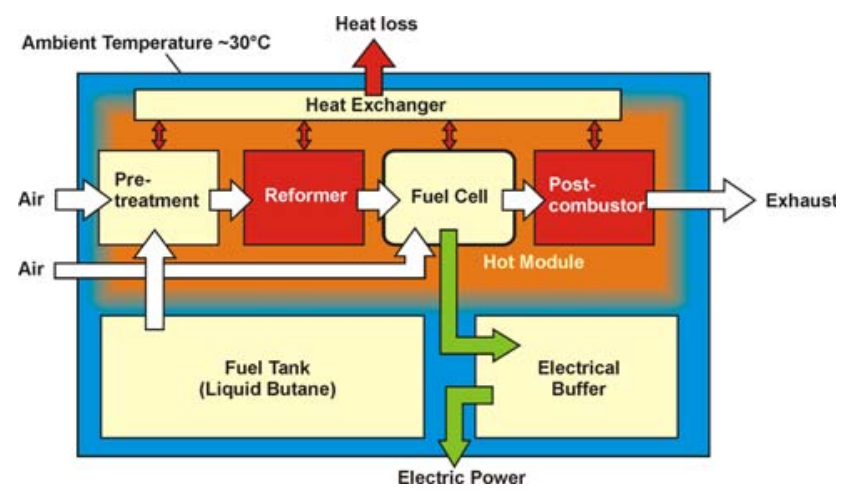

Fig. 3 Layout of the ONEBAT micro-SOFC system (M. Stutz, Laboratory of Thermodynamics, ETH Zurich, Switzerland) [72]

SOFC system will be presented separately in the following sections.

\section{PEN element and fuel cell performance}

The PEN elements consisting of free-standing multilayer membranes are fabricated on Foturan ${ }^{\circledR}$ glass ceramic substrates (Fig. 4) and silicon substrates using thin film deposition and microfabrication techniques. The prime aim being pursued in fuel cell development is the fabrication of micro-SOFC membranes that can withstand the operating conditions $\left(300-600{ }^{\circ} \mathrm{C}\right.$ ) and that provide a considerable power output. This is not easy, since ceramic thin films and typical substrate materials have different thermal expansion coefficients, which could result in a reduced mechanical stability of the free-standing membrane.

In the ONEBAT system, both Foturan ${ }^{\circledR}$ glass ceramic and silicon substrates were used to develop free-standing micro-SOFC membranes. The processing scheme for Foturan ${ }^{\circledR}$-based micro-SOFCs is given in [7], and the silicon processing is described in Refs. [23, 24].

It was seen that for the micro-SOFC membranes processed on Foturan ${ }^{\circledR}$, a crack-free multilayer consisting of a dense yttria-stabilized zirconia (YSZ) electrolyte and porous platinum electrodes is stable up to $600{ }^{\circ} \mathrm{C}$ (Fig. 5) [7]. The active free-standing membrane has a diameter of

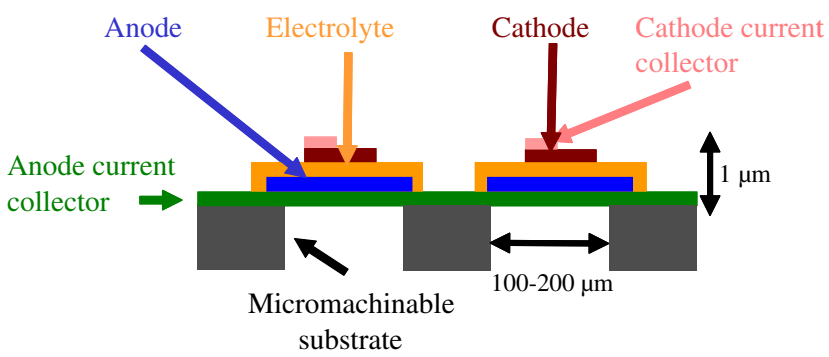

Fig. 4 Schematic drawing of Foturan ${ }^{\circledR}$-based micro-SOFC membranes (adapted from [56]) 


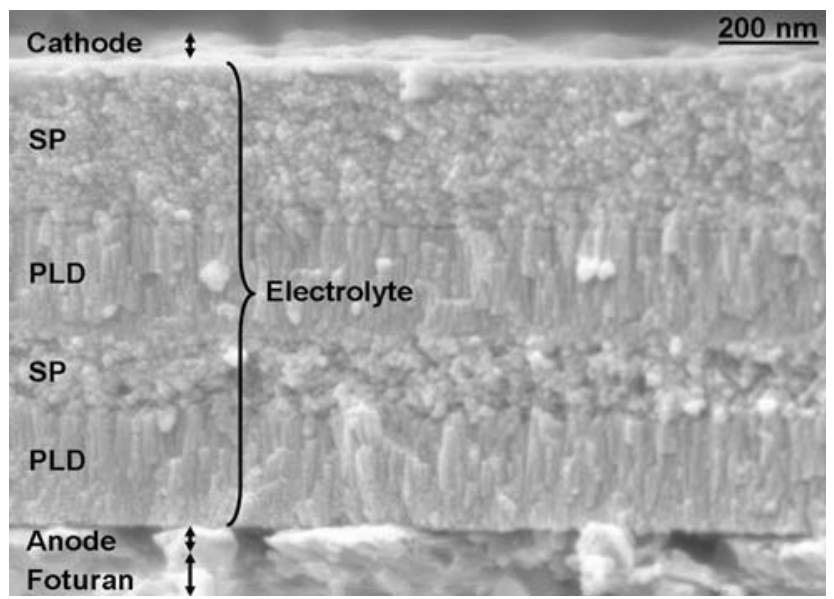

Fig. 5 Multilayer PEN element deposited on a Foturan ${ }^{\circledR}$ substrate. The quadrilayer $8 \mathrm{~mol} \%$ yttria-stabilized zirconia electrolyte with alternating pulsed laser deposition $(P L D)$ and spray pyrolysis $(S P)$ layers is between the sputtered Pt anode and cathode. The total thickness of the free-standing PEN membrane is $\sim 1 \mu \mathrm{m}$ (adapted from [56])

$100 \mu \mathrm{m}$, and the total thickness of the PEN-element is $\sim 1 \mu \mathrm{m}$. The performance of a micro-SOFC of this type is shown in Fig. 6. An almost theoretical OCV of $1.06 \mathrm{~V}$ and a power output of $150 \mathrm{~mW} \mathrm{~cm}{ }^{-2}$ at $550{ }^{\circ} \mathrm{C}$ were obtained using humidified $\mathrm{H}_{2}: \mathrm{N}_{2}(1: 4)$ as the fuel gas and air as the oxidant on the cathode side [7]. A maximum performance of $238 \mathrm{~mW} \mathrm{~cm}{ }^{-2}$ at $550{ }^{\circ} \mathrm{C}$ has been achieved for Foturan ${ }^{\circledR}$-based micro-SOFCs.

The silicon-based micro-SOFCs consist of free-standing membranes that are fabricated with a supporting grid reinforcement [15]. This nickel grid not only leads to a higher mechanical stability by increasing the buckling limit of the membrane, but also serves as the current collector on the anode side. The free-standing membranes with a

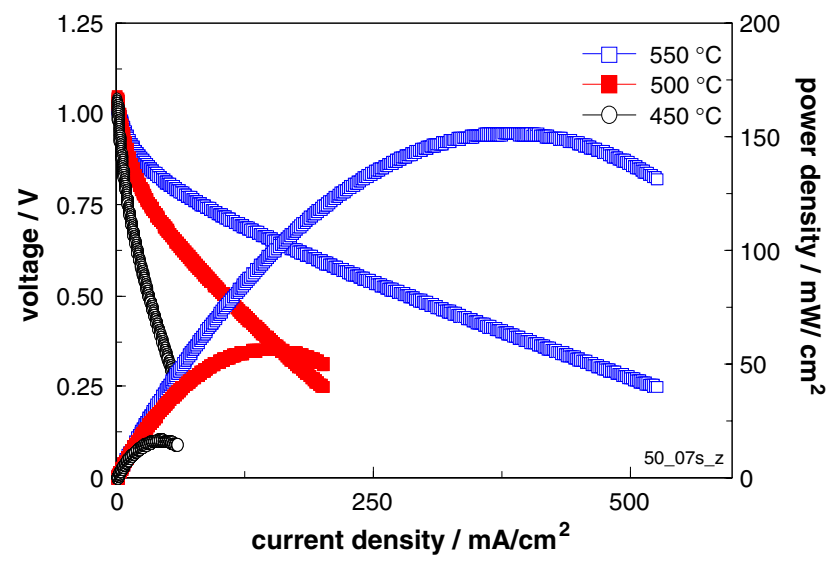

Fig. $6 U-I$ and performance curves of Foturan ${ }^{\circledR}$-based cells: sputtered $\mathrm{Pt}$ anode $(35-50 \mathrm{~nm}) / \mathrm{YSZ}$ pulsed-laser deposited electrolyte $(550 \mathrm{~nm}) / \mathrm{YSZ}$ spray pyrolysis electrolyte $(200 \mathrm{~nm}) / \mathrm{Pt}$ paste cathode $(10-20 \mu \mathrm{m})$ (adapted from [72]) diameter up to $5 \mathrm{~mm}$ and with a thickness of $200 \mathrm{~nm}$ were crack-free up to $350{ }^{\circ} \mathrm{C}$, and an OCV of $0.28 \mathrm{~V}$ was obtained for a micro-SOFC consisting of platinum electrodes and a YSZ electrolyte [15].

The micro-SOFC performance very much depends on the materials used and the microstructure of the different thin films, which can be varied by the choice of deposition method. The electrical properties of the free-standing membrane layers are discussed in more detail in the next main chapter of this paper.

\section{Gas-processing unit}

The combination of the PEN fuel cell element and the gasprocessing unit is referred to as the hot module. The gasprocessing unit consists of a reformer and a post-combustor to process butane to syngas and to post-combust the SOFC exhaust in micro-reactors [5]. The main goal is to achieve a high catalytic performance for these two components at a relatively low operating temperature of $550{ }^{\circ} \mathrm{C}$. Figure 7 shows that butane conversion of $90 \%$, hydrogen selectivity of $81 \%$, and carbon monoxide selectivity of $66 \%$ were achieved for an extremely small reactor volume of $40 \mathrm{~mm}^{3}$ containing $10 \mathrm{mg}$ catalytic $\mathrm{Rh} /$ ceria/ zirconia nanoparticles for a total inlet flow rate of $0.34 \mathrm{~g} \mathrm{~h}^{-1}$ butane [20]. This corresponds to an exergy content of $2.2 \mathrm{~W}$. Furthermore, it was shown that a combination of partial oxidation, steam reforming, and dry reforming of butane takes place in different regions of the reactor [25]. The catalyst fills the cavities between the two bonded silicon wafers as shown in Fig. 8. This novel diskshaped reactor design, which fits in well with the geometry of the entire system, showed a very stable catalytic performance $(<1 \%$ deactivation $)$ for $>30 \mathrm{~h}$. This is a significant improvement compared to conventional tubular reactors. These results have been obtained with test catalysts; the integration into the microfabricated micro-SOFC system has not yet been accomplished.

\section{Thermal system}

The main question concerning thermal management within a micro-SOFC system is whether it is possible to achieve the big temperature differential between the hot module inside the system $\left(550{ }^{\circ} \mathrm{C}\right)$ and a safe handling temperature on the exterior $\left(35^{\circ} \mathrm{C}\right)$. Two- and three-dimensional thermo-fluidic finite element models were set up in order to simulate the temperature distribution within the hot module as a whole, as well as just in the fuel cell stack. It was found that a temperature drop of about $500{ }^{\circ} \mathrm{C}$ from the inside to the outside is feasible with excellent stack insulation and an efficient heat exchange between the exhaust gases and the inflowing anode and cathode gases [5]. 
Fig. 7 Butane conversion $\eta$, hydrogen selectivity $S_{\mathrm{H} 2}$, and carbon monoxide selectivities $S_{\mathrm{CO}}$ for a disk-shaped reactor volume of $40 \mathrm{~mm}^{3}$ at total inlet flow rates $\dot{V}_{\text {gas,in }}$ of $10,15,20$, 25 , and $30 \mathrm{sccm}$ and a reactor temperature of $550{ }^{\circ} \mathrm{C}(\mathrm{N}$. Hotz, Laboratory of Thermodynamics, ETH Zurich, Switzerland) [72]
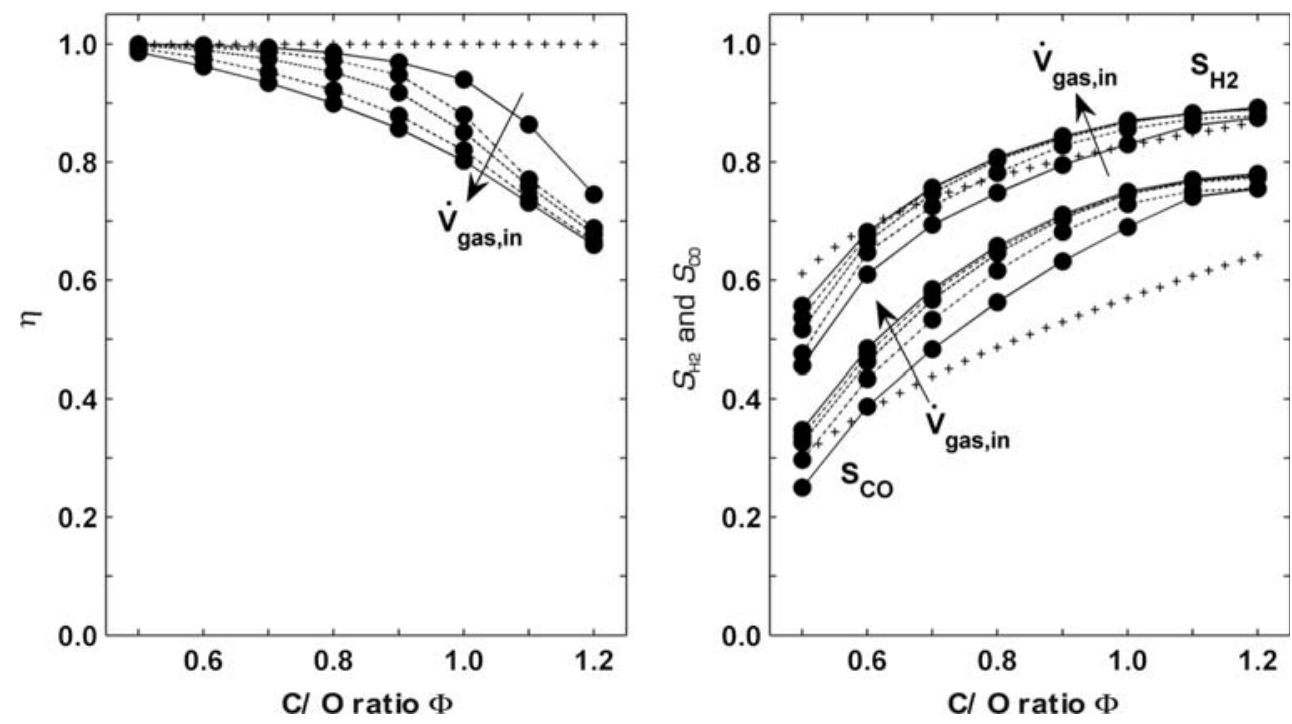
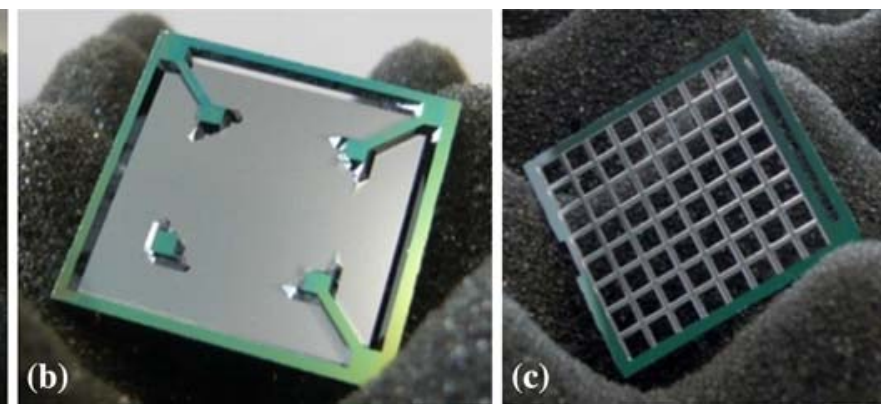

Fig. 8 Individual elements of the gas-processing unit fabricated by silicon technology: a post-combustor top; b post-combustor bottom; c interconnector (P. Heeb, Interstate University of Applied Sciences of Technology, Buchs, Switzerland) [72]

The startup process of the micro-SOFC system uses the exothermal butane oxidation as a heat source to reach the operation temperature of $550{ }^{\circ} \mathrm{C}$. This novel startup process is more than twice as fast and efficient compared to a conventional startup using only electrical energy [17, 19].

\section{Micro-SOFC system development}

It has been shown that the individual micro-SOFC subsystems described in the previous sections all work. The high power output from the electrochemical part can be increased by improving the materials and microstructure of the PEN membrane. Model systems for gas processing and thermal management have been fabricated for initial tests. A rectangular, multiwafer design for the hot module has been proposed, as depicted in Fig. 9. The integration of the hot module into a micro-SOFC system is, however, still pending. The main issues concern multiple wafer bonding and harsh operating conditions, such as high temperatures, oxidizing and reducing gas atmospheres.

A cost estimation for the total micro-SOFC system shows that it is comparable to the cost of laptop batteries.
In this regard, a micro-SOFC system such as the ONEBAT system is technically feasible as a power source for portable devices.

\section{Micro-SOFC PEN-membrane thin films}

In addition to the system approach discussed in the previous chapter, several research groups have focused on the development of PEN elements for micro-SOFCs, i.e., on thin films for electrolytes and electrodes [7, 9, 15, 23, 24, 26-30]. The properties of these materials used in electrolyte and electrode thin film micro-SOFCs are discussed in this section.

\section{Electrolyte}

State-of-the-art electrolyte materials for micro-SOFC membranes are ionic-conducting YSZ ( $8 \mathrm{~mol} \%$ ) and mixed ionic-electronic conducting gadolinia-doped ceria (CGO, $10 \mathrm{~mol} \%$ ). In order to achieve a good overall performance in the micro-SOFC, the microstructure of the electrolyte 
Fig. 9 Planar, rectangular, multi-wafer design of the hot module (P. Heeb, Interstate University of Applied Sciences of Technology, Buchs, Switzerland) [72]

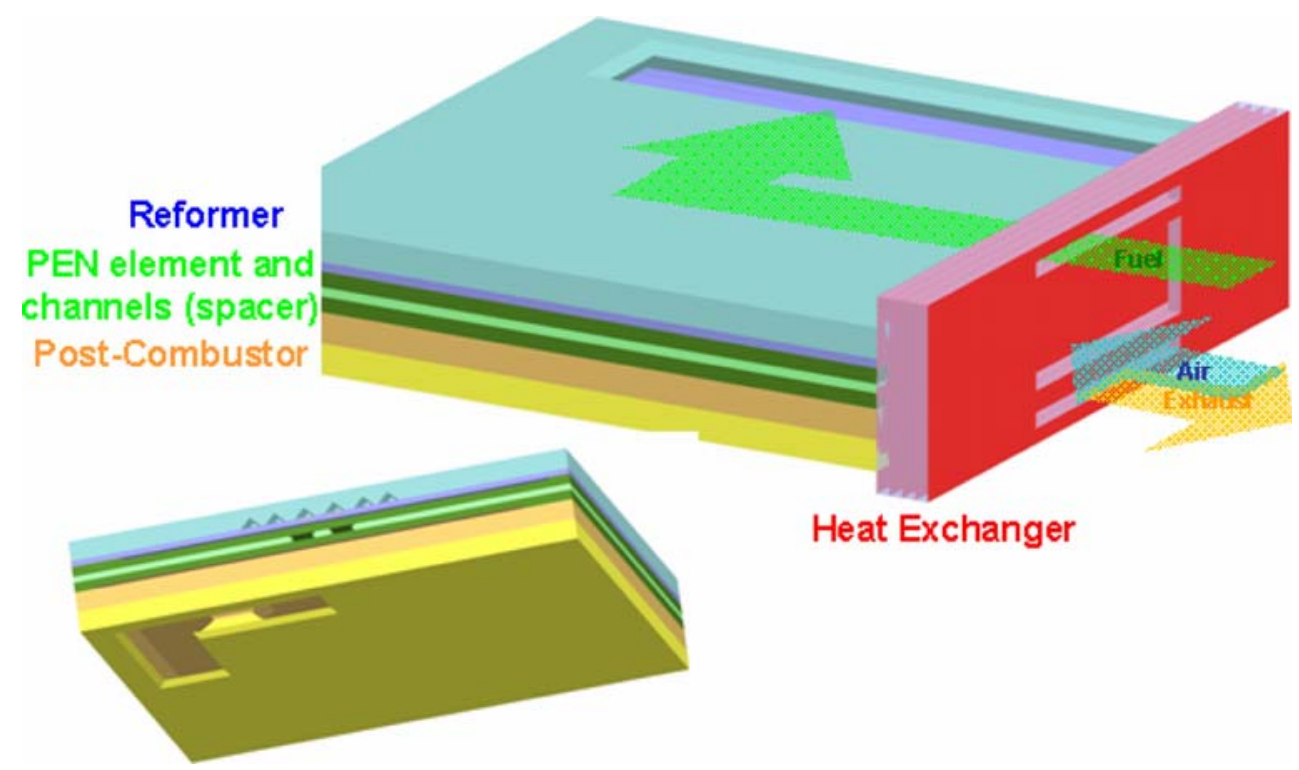

has to be in the form of a thin film (i.e., a low ohmic resistance) and be gas-tight and of high ionic conductivity. It is not known yet whether the films have to be crystalline. Nanocrystalline electrolyte thin films differ substantially in their thermal stability [31-33], electrical conductivity, and thermodynamic stability [10, 34-38] from conventional microcrystalline oxides. Microstructural features, such as the small grain size, texture, varying degrees of crystallinity, residual amorphous phases, and microstrains, form the nanoimpact on thermal and electric properties of electrolyte thin films. It was seen that nanocrystalline materials show unusual electrical conductivities [39-42] and thermal stabilities [43-45], because of the large amount of grain boundaries these materials contain in relation to the grain volume. In the case of nanocrystalline thin films, stresses within the films, which result from thermal expansion mismatch between the substrate and the thin films, can affect the electrical properties and must be taken into consideration for their application in SOFCs [46]. Furthermore, it was shown that residual amorphous phases of nanocrystalline ceria-based films result in selflimited grain growth with stable microstructures after short annealing times [31, 33]. This is highly advantageous in terms of the thermal stability of electrolyte thin films for micro-SOFCs. In general, it can be concluded for both YSZ and CGO that the electrical conductivity of thin films is almost one order of magnitude lower for the nano-thin films than for the microcrystalline bulk material of a comparable composition [6, 44, 47-51].

\section{Electrodes}

The electrodes of a micro-SOFC membrane should be porous in order to allow a sufficient gas exchange at the gas-electrolyte-electrode interface. Furthermore, the materials should be good mixed ionic-electronic conductors with good catalytic activity promoting fuel oxidation (anode) and oxygen reduction (cathode). Up till now, sputtered platinum thin films have been the most common electrodes for micro-SOFCs [7, 24]. The anode thin films are deposited on an insulating micro-SOFC substrate, such as Foturan ${ }^{\circledR}$ or silicon wafers coated with a silicon nitride $\left(\mathrm{Si}_{3} \mathrm{~N}_{4}\right)$ or silicon dioxide $\left(\mathrm{SiO}_{2}\right)$ insulating layer. It is known that metallic films, deposited on insulating substrates via MEMS techniques, are in a metastable state and suffer degradation of microstructure over time at elevated temperatures due to Ostwald ripening [52-55]. The degree of porosity is a function of the thickness and the annealing of the thin films [56]. A controlled degradation is thus necessary to guarantee sufficient pores for fuel gas access and to maintain a closed metal network for in-plane electronic conduction.

Further materials have been investigated for microSOFC anodes: platinum-nickel alloys [55], metallic nickel [28, 30], as well as Ni-YSZ [57], and Ni-CGO [58] cermets in which the electronically conducting nickel forms a pathway for electrons, and the ionically conducting YSZ ceramic network prevents excessive nickel grain growth.

As for the anode, sputtered platinum is the most frequently used cathode. Other common cathode materials in micro-SOFCs with operating temperatures of below $600{ }^{\circ} \mathrm{C}$ are $\mathrm{ABO}_{3}$ perovskites, such as mixed conducting lanthanum strontium cobalt (LSC) oxide [59-61], lanthanum strontium cobalt iron oxide (LSCF) [62-66] and barium strontium cobalt iron oxide (BSCF) [67-69]. Most of the studies reported so far in the literature on cathodes for micro-SOFCs essentially focus on the investigation of oxygen reduction mechanisms with geometrically well- 


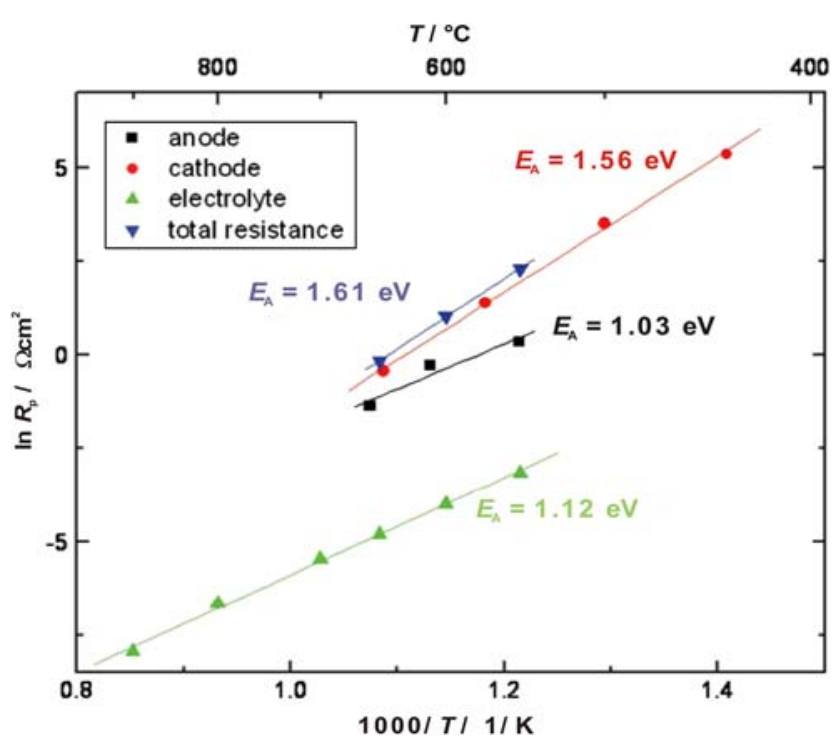

Fig. 10 Measured resistances of single anode, electrolyte, and cathode thin films (area $=1 \mathrm{~cm}^{2}$ ) and predicted total cell resistance of tri-layer as a function of the temperature. While the resistances of the electrodes were determined by electrochemical impedance spectroscopy, the resistances of the electrolyte were calculated from a four-point conductivity measurement [70]

defined model electrodes. Only a few publications have been devoted to the fabrication and processing-related issues. This is important, however, since the cathode is generally considered as being the limiting factor in microSOFC performance, as shown in Fig. 10 [70].

\section{Micro-SOFCs membrane development: unsolved tasks}

The example of the ONEBAT system shows that a microSOFC system of this type can potentially be used as a power supply for portable devices. Furthermore, investigations have been carried out into the microstructure and electrochemical properties of thin films for micro-SOFC. However, there are still many remaining aspects, in particular with regard to micro-SOFC membranes, which are not yet fully understood and require further research and development.

The lower operation temperature range of micro-SOFCs $\left(300-600{ }^{\circ} \mathrm{C}\right)$ compared to stationary SOFCs $\left(900{ }^{\circ} \mathrm{C}\right)$ is linked to the question of which materials are most suitable for the anode, electrolyte, and cathode under these conditions. So far, the conventional high temperature materials are used for low temperature applications.

In addition, the butane catalysis on the anode side must be considered in order to find the best combination of anode material and gas composition at these lower temperatures, since coking of the fuel cell must be prevented. What happens on the anode side when butane is directed onto the material? How large is the probability of carbon deposition at these temperatures, and how can it be prevented?

Up until now, it has not been clear how the microstructures (columnar or grained microstructure, grain size, degree of crystallinity) of fuel cell membranes affect their electrical conduction and hence the overall micro-SOFC performance. Further detailed investigations are required, in particular, into the pronounced scatter of the activation energies and electrical conductivity properties for YSZ and CGO thin films. Possible reasons might be the different microstructure, space charge effects, or stress, which are caused by differences in the film deposition conditions, such as vacuum vs. non-vacuum methods, dry vs. wet deposition, and amorphous vs. crystalline deposited thin films. In addition, the grain and grain boundary contribution, as well as the residual amorphous phase contribution to the total conductivity in thin films, is not well elaborated.

The cathode is generally considered as the limiting factor in micro-SOFC performance [70]. Future incorporation of cathode materials with lower polarization resistances is targeted. The perovskite defect models and the required triple-phase boundary lengths thus need to be optimized. Further research must be done to show what a good cathode should look like and whether it is necessary to have mixed ionic-electronic cathode materials. Therefore, the ionic and electronic conductivity contributions of mixed-conducting thin films must be separated. This has, however, not been done to a satisfying extent in the literature.

The optimal substrate material for micro-SOFCs has not yet been found, since both substrate materials that were introduced as micro-SOFC substrates in the literature, Foturan $^{\circledR}$ glass ceramic and silicon wafers, have drawbacks during processing and operation. The etching of Foturan ${ }^{\circledR}$ requires hydrofluoric acid, which can attack the electrochemically active thin films. With silicon wafer substrates, an electrically insulating thin film layer, such as silicon nitride, is required; however, the presence of pinholes within the silicon nitride insulation layer can easily cause short circuits between the silicon substrate and the microSOFC membrane.

Finally, completely different membrane approaches can be considered in which the load-bearing substrate material is at the same time electrochemically active.

\section{Conclusion}

A micro-SOFC system approach such as the ONEBAT system seems feasible. The PEN element, gas-processing unit, and thermal management subsystems are tested and 
characterized. Further optimization is required, and there are many open issues that have to be solved in the next years. These micro-SOFC systems seem to be promising alternatives to state-of-the-art batteries in portable electronics.

Acknowledgments Financial support from the following Swiss institutions for the ONEBAT and NANCER projects is gratefully acknowledged: Commission for Technology and Innovation (CTI), Competence Centre for Energy and Mobility (CCEM), Competence Centre for Materials Science and Technology (CCMX), Bundesamt für Energie (BfE), and Swiss Electric Research (SER).

\section{References}

1. Kundu A, Jang JH, Gil JH, Jung CR, Lee HR, Kim SH, Ku B, Oh YS (2007) J Power Sources 170(1):67

2. La O' GJ, In HJ, Crumlin E, Barbastathis G, Shao-Horn Y (2007) Int J Energy Res 31(6-7):548

3. Schaevitz SB, Franz A, Barton R (2005) US 2005/0115889

4. Schaevitz SB, Franz A, Barton R, Ludwiszewski AP (2006) US 2006/0263655

5. Bieberle-Hutter A, Beckel D, Infortuna A, Muecke UP, Rupp JLM, Gauckler LJ, Rey-Mermet S, Muralt P, Bieri NR, Hotz N, Stutz MJ, Poulikakos D, Heeb P, Muller P, Bernard A, Gmur R, Hocker T (2008) J Power Sources 177:123

6. Infortuna A, Harvey AS, Gauckler LJ (2008) Adv Funct Mater 18:127

7. Muecke UP, Beckel D, Bernard A, Bieberle-Hütter A, Graf S, Infortuna A, Müller P, Rupp JLM, Schneider J, Gauckler LJ (2008) Adv Funct Mater 18:1

8. Muecke UP, Akiba K, Infortuna A, Salkus T, Stus NV, Gauckler LJ (2008) Solid State Ionics 178(33-34): 1762

9. Beckel D, Bieberle-Hutter A, Harvey A, Infortuna A, Muecke UP, Prestat M, Rupp JLM, Gauckler LJ (2007) J Power Sources 173:325

10. Rupp JLM, Infortuna A, Gauckler LJ (2007) J Am Ceram Soc 90(6): 1792

11. Robert G (2004) EP 1455409 A1

12. Gauckler LJ, Beckel D, Muecke UP, Müller P, Rupp JLM (2007) WO2007/045111

13. Gauckler LJ, Beckel D, Muecke UP, Müller P, Rupp JLM (2007) WO2007/045113

14. Beckel D, Gauckler LJ (2007) WO2007056876-A1; EP1951641A1

15. Rey-Mermet S, Muralt P (2008) Solid State Ionics 179(2732): 1497

16. Rey-Mermet S, Muralt P, Baborowski J (2007) PCT/EP2006/ 069688

17. Stutz MJ, Grass RN, Loher S, Stark WJ, Poulikakos D (2008) J Power Sources 182(2):558

18. Stutz MJ, Hotz N, Poulikakos D (2006) Chem Eng Sci 61(12):4027

19. Stutz MJ, Stark WJ, Poulikakos D (2007) EP 07012131

20. Hotz N, Stutz MJ, Loher S, Stark WJ, Poulikakos D (2007) Appl Catal B 73(3-4):336

21. Hotz N, Senn SM, Poulikakos D (2006) J Power Sources 158(1):333

22. Hotz N, Poulikakos D, Studart AR, Bieberle-Hütter A, Gauckler LJ (2008) EP 08012273

23. Baertsch CD, Jensen KF, Hertz JL, Tuller HL, Vengallatore ST, Spearing SM, Schmidt MA (2004) J Mater Res 19(9):2604
24. Huang H, Nakamura M, Su PC, Fasching R, Saito Y, Prinz FB (2007) J Electrochem Soc 154(1):B20

25. Hotz N, Osterwalder N, Stark WJ, Bieri NR, Poulikakos D (2008) Chem Eng Sci 63(21):5193

26. Su PC, Chao CC, Shim JH, Fasching R, Prinz FB (2008) Nano Lett 8(8):2289

27. Shim JH, Chao CC, Huang H, Prinz FB (2007) Chem Mater 19(15):3850

28. Kang S, Su PC, Park YI, Saito Y, Prinz FB (2006) J Electrochem Soc 153(3):A554

29. Kwon C-W, Son J-W, Lee D-J, Kim K-B, Lee J-H, Lee H-W (2008) In: Lucerne Fuel Cell Forum, Lucerne

30. Joo JH, Choi GM (2008) J Power Sources 182(2):589

31. Rupp JLM, Infortuna A, Gauckler LJ (2006) Acta Mater 54(7): 1721

32. Rupp JLM, Solenthaler C, Gasser P, Muecke UP, Gauckler LJ (2007) Acta Mater 55(10):3505

33. Rupp JLM, Scherrer B, Harvey A, Gauckler LJ (2009) Adv Funct Mater (in review)

34. Knauth P, Tuller HL (2000) Solid State Ionics 136:1215

35. Chiang YM, Lavik EB, Kosacki I, Tuller HL, Ying JY (1996) Appl Phys Lett 69(2):185

36. Kosacki I, Suzuki T, Anderson HU, Colomban P (2002) Solid State Ionics 149(1-2):99

37. Maier J (2003) Z Phys Chem 217(4):415

38. Steele BCH (2000) Oxygen ion and mixed conductors and their technological applications, vol 368. Springer, Erice, p 323

39. Greenberg M, Wachtel E, Lubomirsky I, Fleig J, Maier J (2006) Adv Funct Mater 16(1):48

40. Perednis D, Gauckler LJ (2004) Solid State Ionics 166(3-4):229

41. Perednis D, Gauckler LJ (2003) Solid oxide fuel cells VIII (SOFC VIII). In: 8th international symposium on solid oxide fuel cells, Paris, 27 Apr 2003-2 May 2003. vol 7. Electrochemical Society Inc, Pennington, p 970-975

42. Hertz JL, Tuller HL (2004) J Electroceram 13(1-3):663

43. Kosacki I, Rouleau CM, Becher PF, Bentley J, Lowndes DH (2005) Solid State Ionics 176(13-14):1319

44. Kosacki I, Suzuki T, Petrovsky V, Anderson HU (2000) Solid State Ionics 136:1225

45. Chiodelli G, Malavasi L, Massarotti V, Mustarelli P, Quartarone E (2005) Solid State Ionics 176(17-18):1505

46. Atkinson A, Ramos TMGM (2000) Solid State Ionics 129(14):259

47. Joo JH, Choi GM (2006) Solid State Ionics 177(11-12):1053

48. Heiroth S, Lippert T, Wokaun A, Döbeli M (2008) Appl Phys A: Mater Sci Process 93:639

49. Huang H, Gur TM, Saito Y, Prinz F (2006) Appl Phys Lett 89(14): 143107

50. Suzuki T, Kosacki I, Anderson HU (2002) Solid State Ionics 151(1-4): 111

51. Rupp JLM, Gauckler LJ (2006) Solid State Ionics 177(2632): 2513

52. Srolovitz DJ, Yang W, Goldiner MG (1996) Polycrystalline thin films: structure, texture, properties, and applications II. In: Conference on polycrystalline thin films-structure, texture, properties, and applications II, Boston, 27 Nov 1995-1 Dec 1995. vol 403. Materials Research Soc, Pittsburgh, p 3-13

53. de Gennes PG (1985) Rev Mod Phys 57(3):827

54. Brochard Wyart F, Daillant J (1990) Can J Phys 68(9):1084

55. Wang XH, Huang H, Holme T, Tian X, Prinz FB (2008) J Power Sources 175:75

56. Rupp JLM, Bieberle-Hütter A, Evans A, Galinski H, Ryll T, Scherrer B, Tölke R, Gauckler LJ (2008) In: European Fuel Cell Forum, Lucerne

57. La O' GJ, Hertz J, Tuller H, Shao-Horn Y (2004) J Electroceram 13(1-3):691 
58. Muecke UP, Graf S, Rhyner U, Gauckler LJ (2008) Acta Mater 56(4):677

59. Peters C, Weber A, Ivers-Tiffee E (2008) J Electrochem Soc 155(7):B730

60. Bieberle-Hutter A, Tuller HL (2006) J Electroceram 16(2):151

61. Bieberle-Hutter A, Sogaard M, Tuller HL (2006) Solid State Ionics 177(19-25): 1969

62. Steele BCH, Bae JM (1998) Solid State Ionics 106(3-4):255

63. Prestat M, Koenig JF, Gauckler LJ (2007) J Electroceram 18(12):87

64. Prestat M, Infortuna A, Korrodi S, Rey-Mermet S, Muralt P, Gauckler LJ (2007) J Electroceram 18(1-2):111

65. Baumann FS, Fleig J, Cristiani G, Stuhlhofer B, Habermeier HU, Maier J (2007) J Electrochem Soc 154(9):B931

66. Beckel D, Muecke UP, Gyger T, Florey G, Infortuna A, Gauckler LJ (2007) Solid State Ionics 178(5-6):407
67. Shao ZP, Haile SM (2004) Nature 431(7005):170

68. Baumann FS, Fleig J, Habermeier HU, Maier J (2006) Solid State Ionics 177(35-36):3187

69. Baumann FS, Maier J, Fleig J (2008) Solid State Ionics 179:1198

70. Bieberle-Hutter A, Beckel D, Muecke UP, Rupp JLM, Infortuna A, Gauckler LJ (2005) Mst News 04/05:12

71. Manhattan Scientifics \& Lawrence Livermore National Laboratories and Sulzer Hexis (2002) Personal communication

72. Bieberle-Hutter A, Beckel D, Galinski H, Infortuna A, Muecke UP, Rupp JLM, Ryll T, Scherrer B, Toelke R, Gauckler LJ, Rey-Mermet S, Muralt P, Bieri NR, Hotz N, Stutz MJ, Poulikakos D, Heeb P, Bernard A, Gmur R, Hocker T (2008) In: European Fuel Cell Forum, Lucerne

73. Thomas G (2003) Invited BES hydrogen workshop presentation. Sandia National Laboratories, Albuquerque 